\title{
DA RACIONAIIDADE
}

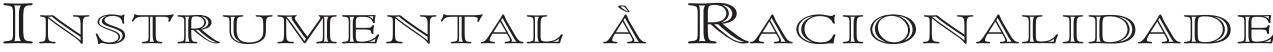 COMUNICATIVA: O CASO DE UMAA INSTITUIÇÃO PSIQUIÅTRICA}

\author{
Fabio Vizeu**
}

\section{RESUIMO}

presente trabalho consiste em uma pesquisa teórico-empírica sobre racionalidade nas organizações. Neste sentido, segue a mesma linha de trabalhos que vêm realizando estudos empíricos sobre organizações substantivas. Procuramos abordar a transição da racionalidade instrumental para a racionalidade comunicativa a partir do caso de um hospital psiquiátrico. Para tanto, abordou-se o movimento de reforma institucional que vem ocorrendo nesse tipo de organização. A orientação epistemológica do movimento denominado por reforma psiquiátrica dá consistência à idéia de que as recentes transformações nessas organizações têm forte relação com os pressupostos da razão comunicativa. Na parte empírica deste trabalho, foi utilizada a observação participante. Os resultados da pesquisa apontaram ser a principal orientação racional do caso investigado a comunicativa, o que corroborou a hipótese de trabalho inicialmente constituída.

$\mathbb{A B S T R A C T}$

he present work consists a research on rationality in the organizations. In this direction, it follows the studies on substantive organizations. Ours aims was the transition of instrumental rationality to communicative rationality, in case of a psychiatric hospital. For in such a way, the movement of psychiatric institutional reform was approached. The epistemological orientation of this movement gives consistency to the idea that the recent transformations in these organizations occur in direction of communicative rationality. In the empirical part of this work, the participant observation was used. The results of the research had pointed the communicative rationality as the main rational orientation in organization investigated, what it corroborated the hypothesis of work initially consisting.

* O autor agradece as sugestões feitas pelos pareceristas da O\&S, as quais contribuíram para a melhoria deste trabalho.

** Prof. Unicenp e doutorando EAESP/FGV 
questão da racionalidade vem sendo cada vez mais enfocada pelos estudos organizacionais. Desde a denúncia sobre a falácia do racionalismo moderno empreendida pela escola de Frankfurt, a perspectiva acerca da racionalidade predominante em nossa sociedade se alterou, passando a ser observada como mais uma forma de dominação e alienação na sociedade capitalista (ASSOUN, 1991). Na verdade, o caráter econômico da racionalidade instrumental que se desenvolveu na modernidade corresponde, satisfatoriamente, ao ethos do capitalismo recente. Nesse sentido, observamos que nenhuma outra área de conhecimento está mais diretamente relacionada ao entendimento das conseqüências do racionalismo moderno do que a Administração, justamente, pelo fato dessa ter sido fortemente condicionada pela racionalidade instrumental.

Desde o notório trabalho de Ramos (1989), vem surgindo no Brasil um significativo número de trabalhos que visam a investigar formas de racionalidade alternativas à razão instrumental. Destacasse a obra de Ramon Garcia por sua importante contribuição para o avanço da proposta de Ramos (1989). Ao tratar da questão da emancipação, Ramon Garcia recorre à teoria de Habermas para indicar a possibilidade de concretização da emancipação pela auto-gestão dos grupos, afastando-se do entendimento ingênuo sobre auto-gestão da literatura gerencial dominante, ou seja, reconstituindo uma possibilidade de coordenação que não é opressora, justamente por não ser distorcida pela lógica racional-instrumental dos sistemas econômico e político contemporâneos. Nesse intento, a obra de Ramon Garcia promove pioneiramente a aproximação entre a proposta da racionalidade substantiva de Ramos (1989) e a teoria da ação comunicativa de Habermas (1987), e inaugura um proveitoso refinamento teórico para os chamados estudos sobre organizações substantivas (GUTIERREZ, FREITAS e CATANI, 2004).

Apesar do grande avanço obtido pelos estudiosos da racionalidade nas organizações, pouco se abordou sobre o processo de transição da orientação racional-instrumental para a forma racional-substantiva (ou racional-comunicativa). 0 foco de muitos estudos teórico-empíricos tem sido o de identificar a predominância de uma ou de outra forma (por exemplo, SERVA [1996]; ANDION [2001]); por outro lado, apesar de outros autores já estarem indicando a ruptura com a orientação racional-instrumental em certos setores e/ou tipos organizacionais (TENÓRIO, 2000), carece, ainda assim, de maior volume de estudos empíricos.

Uma significativa contribuição para o avanço nas pesquisas sobre racionalidade seria identificar empiricamente as possibilidades de transição para a razão substantiva em organizações nas quais, por questões contextuais e mesmo históricas, predominou a lógica racional-instrumental. Esses estudos podem promover elucidações proveitosas, seja para o meio acadêmico ou mesmo para a sociedade de modo geral: por um lado, quanto à possibilidade de uma organização questionar-se sobre as contradições da racionalidade instrumental e permitirse à construção de um novo caminho, mas também, por revelar em que sentido a sociedade civil tem efetivamente se mobilizado para a construção de novos modelos organizacionais.

Assim, o presente estudo visa a atender a esta última proposição, ou seja, empreender um estudo empírico sobre racionalidades, de maneira a evidenciar a transição de uma forma institucional predominantemente racional-instrumental para outra centrada na lógica da racionalidade comunicativa. Para tanto, optamos por focalizar um tipo de organização historicamente marcado por forte conotação racional-instrumental, mas que, devido à crescente mobilização da sociedade civil, vem delineando-se em uma nova forma que valoriza aspectos e pressupostos da racionalidade comunicativa. A organização pesquisada é a instituição psiquiátrica, denominada em certo tempo como uma burocracia totalizante e altamente degenerativa da personalidade do indivíduo (GOFFMAN, 1996), mas, recentemente, marcada por uma transformação institucional que tem por principal objetivo valorizar a condição humana do doente mental. 
Seguimos com a apresentação do trabalho. Primeiramente, tratamos da fundamentação teórica e conceitual da teoria habermasiana, dando ênfase ao seu uso na Administração. Em seguida, apresentamos o resultado do trabalho empírico empreendido.

\section{LIMIITES DO RAGIONAIISMIO} NA $\mathbb{A} D \mathbb{M} I N I S T R A C G \tilde{A} O$

Especialmente a partir do pensamento administrativo, as organizações tiveram forte direcionamento tecno-econômico em suas principais formas de abordagens, o que determinou a hegemonia de uma racionalidade do tipo instrumental nesse campo. Isto se deu, em particular, graças à influência do modelo burocrático weberiano sobre os sociólogos que constituíram a chamada teoria da organização formal.

A despeito do progresso obtido por essa forma de racionalismo no corpo de conhecimentos sobre organizações, nos últimos anos, alguns autores têm criticado a validade da diretriz racional, justamente por considerar ser tal progresso restrito à esfera econômica. Ramos (1989) questiona o direcionamento racional da teoria organizacional sugerindo ser este limitado a um contexto específico, o da sociedade de mercado, e que tal orientação não pode condicionar satisfatoriamente todos os enclaves da vida humana associada. Segundo esse autor, a limitação se deve por se configurar o entendimento de racionalidade apenas sob a forma instrumental.

A racionalidade instrumental pode ser definida como o cálculo utilitário de conseqüências e, tanto na concepção aristotélica quanto na perspectiva weberiana sobre ação social, representa apenas uma dimensão de toda a amplitude que pode assumir a questão racional (RAMOS, 1989). A hegemonia da razão instrumental sobre outros tipos tem origem no próprio advento do paradigma científico e econômico-social desenvolvido na era moderna, sustentado pela substituição da perspectiva pré-moderna da razão (que abrangia uma dimensão mais ampla) por uma perspectiva limitada aos preceitos utilitaristas.

Em sua crítica à burocracia moderna, Tragtenberg (1974) ressalta serem as raízes do desenvolvimento da tecnocracia do sistema burocrático a articulação desse mecanismo com o interesse capitalista da maximização dos ganhos econômicos. Mesmo considerando que tal interesse encontra-se nas sociedades atuais de forma mais marcante nas empresas, Tragtenberg (1974) salienta ter sido a subordinação do Estado burocrático ao interesse de uma classe dominante burguesa um dos grandes fatores de desenvolvimento do sistema burocrático retratado por Weber. Assim, tanto na esfera das empresas econômicas quanto no Estado, a lógica burocrática consolida-se graças à sua competência em garantir o avanço do ethos capitalista.

Apesar da associação entre capitalismo e burocracia constar no pensamento weberiano, a originalidade de Tragtenberg (1974) reside no destaque dado por esse autor ao caráter ideológico do racionalismo burocrático defendido pelo pensamento administrativo: a racionalidade das proposições da literatura gerencial reside na efetividade destas quanto à manutenção do interesse da classe econômica dominante, seja constituindo mecanismos cada vez mais eficazes de controle e dominação dos grupos desprivilegiados (operários, funcionários, pacientes, cidadãos etc.), seja constituindo uma falsa consciência da realidade organizacional, apregoada pelo discurso dominante como eminentemente consensual.

A forma que Ramos tenta reconstituir o sentido da razão é por meio da recuperação do conceito weberiano de racionalidade substantiva, este "constituindo um componente intrínseco do ator humano" (RAMOS, 1989, p. 5). Porém, como bem observou Serva (1996), devido à falta de uma base teórica que ofereça uma explicação satisfatória do atributo racional-substantivo sob o ponto de vista da ação social, falta à proposta de Ramos uma fundamentação teórica consistente 
que viabilize como se obter, no âmbito prático da interação social, diretrizes para estruturas e processos organizacionais adequados à racionalidade emancipatória.

A explicação de Habermas sobre o caráter racional da ação social atende a dupla tarefa de prover um entendimento mais ampliado do conceito de razão e de indicar um caminho para a superação das limitações geradas pela orientação racional-instrumental.

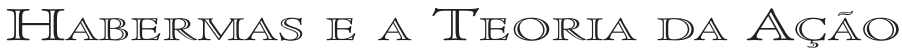 RACIONAL COMUUNICATIVA}

A Teoria da Ação Comunicativa - TAC (HABERMAS, 1987) corresponde a um corpo teórico extremamente denso e de difícil assimilação. Representa a síntese teórica de todo o conjunto da obra mais recente desse autor, em especial, aquela desenvolvida por volta da década de 70, quando Habermas decide reassumir o projeto inicial da escola de Frankfurt, ou seja, encontrar um caminho viável para a racionalidade moderna. Como conseqüência, Habermas afasta-se definitivamente do pessimismo dos outros autores frankfurtianos, especialmente Adorno, Horkheimer e Marcuse (ASSOUN, 1991). Assim, devido aos limites quanto à abrangência do presente texto, torna-se inviável que apresentemos aqui a Teoria da Ação Comunicativa em todos os seus aspectos significativos. Desta forma, nos restringiremos a tratar do ponto que é central em nosso trabalho.

A ação racional proposta por Habermas é denominada comunicativa justamente por causa do pressuposto de que a linguagem é o principal meio de coordenação e interação social. Neste sentido, a teoria desse autor sustenta-se nas abordagens de tradição hermenêutica (mais especificamente, a fenomenologia, o interacionismo simbólico e a lingüística) para constituir sua explicação sociológica. Para Habermas, a linguagem representa um meio intranscendível do sentido, mesmo na atividade subjetiva, o que, por fim, determina categoricamente a condição intersubjetiva através da qualidade de comunidade lingüística.

A partir da reconstrução do atributo 'racional' empreendida pela perspectiva fenomenológica - que considera a intersubjetividade como fundamento básico de determinação da realidade -, Habermas redefine a orientação racional da ação humana. Assim, a racionalidade de uma ação social fica condicionada à capacidade de se sujeitar a críticas e de ser fundamentada por 'boas razões', aceitas pelos membros que pertençam ao mesmo mundo lingüístico de referência. Ao mesmo tempo, em uma situação em que se deve estabelecer uma relação dialógica entre sujeitos agentes presumidamente competentes e independentes, somente se poderá fiar uma ação como sendo racional para ambos (ou mais) participantes se as razões utilizadas para justificar a ação corresponderem a todas as dimensões possíveis dentre as diferentes esferas de mundo de uma relação social - o mundo objetivo, o mundo subjetivo e o mundo normativo.

Neste sentido, Habermas (1987) chama atenção para uma pragmática universal, ou seja, na ação social racional, existem pretensões de validez requeridas nas interações lingüísticas - a pretensão de veracidade, a pretensão de sinceridade, a pretensão de retidão e a pretensão de inteligibilidade dos sujeitos. Tais fatores norteiam a ação social pelo fato desses corresponderem a justificações pressupostas em todo ato lingüístico, as quais servem para condicionar o atributo racional de uma forma dialógica (SACHUK E MACHADO, 2004).

Em contrapartida, quando uma ação racional se reveste na forma instrumental, esta passa a ser delineada como uma 'ação estratégica', pois, pelo fato da intenção de um dos sujeitos ser a intervenção no mundo objetivo através do outro, a ação perde sua natureza dialógica: para o sujeito agente, a ação é racional apenas em relação à esfera de mundo objetivo; ainda, o outro sujeito se configura como um meio para o alcance de objetivos e, assim, torna-se um objeto. 


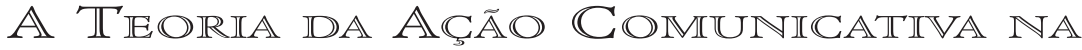 ÁREA DE ESTUUDOS ORGANIZACIONAIS}

Nos últimos anos, tem sido profícuo, no Brasil, o desenvolvimento de Estudos Organizacionais relacionados à teoria de ação comunicativa de Habermas e à abordagem organizacional substantiva de Ramos ${ }^{1}$. Seja no formato de ensaio teórico ou como estudos teórico-empíricos, esses trabalhos têm procurado aprofundar o entendimento na área sobre questões específicas - por vezes negligenciadas ou indevidamente tratadas em sua complexidade. Os temas recorrentes na articulação com a TAC, além da questão da racionalidade presente na prática organizacional (SERVA, 1996), são de ordem política (seja no âmbito interno da organização ou na dimensão Estatal) como, por exemplo, as questões da democracia e da cidadania (STORINO, 2000; PAULA e MOTTA, 2003; TENÓRIO, DUTRA e MAGALHÃES, 2004; COSTA, 2004), dos processos organizacionais de comunicação (SOUZA, 2002; REIS, 2002; SACHUK e MACHADO, 2004) e, também, aspectos estruturais de novas formas de organizações econômicas, como a chamada Economia Solidária (ANDION, 2001; COSTA, 2004).

Nos estudos recentes que se fundamentam na perspectiva habermasiana, um tema que se destaca é a questão democrática no âmbito das organizações. Evidentemente, esse foco tem sido tratado de forma mais exaustiva no sub-campo da Administração Pública, especialmente no que se refere à articulação de espaços democráticos efetivos, nos quais se viabilize a cidadania. Neste sentido, os estudos ressaltam a idéia que, de acordo com a resignificação do conteúdo racional da ação social empreendida por Habermas, a deliberação coletiva genuinamente democrática somente é possível a partir do consenso atingido pela argumentação livre de constrangimentos discursivos.

Assim sendo, para que se viabilize a gestão democrática capaz de dar conta dos desafios de uma complexidade societária multicultural e economicamente desigual, o poder público deve ser capaz de articular espaços de participação direta do cidadão, os quais favoreçam a competência discursiva deste (TENÓRIO, DUTRA e MAGALHÃES, 2004). Estudos têm chamado a atenção para a importância de medidas públicas específicas de grande potencial para a consecução da cidadania deliberativa, como, por exemplo, o programa do orçamento participativo (PAULA e MOTTA, 2003) e o projeto favela-bairro (STORINO, 2000).

Essas duas medidas, apesar de demonstrarem algumas incongruências com o modelo de gestão social subentendido na ação comunicativa, sinalizam o potencial de tais iniciativas na efetivação das condições processuais necessárias para o estabelecimento de uma forma de gestão pública efetivamente democrática e inclusiva das minorias. Por isso, Paula e Motta (2003) propõem a disseminação exaustiva de novas formas de conselhos e fóruns de articulação dos processos decisórios, fato esse que, certamente, minimizaria os efeitos negativos da orientação tecnoburocrática predominante no Estado brasileiro.

A concepção de articulação dos processos decisórios discursivos verificada na gestão pública também deve ser pensada no âmbito interno das organizações econômicas, justamente porque as contradições da gestão burocrática podem ser observadas em todas as esferas organizacionais da sociedade contemporânea. Neste sentido, Costa (2004) chama a atenção para a necessidade de se articular uma pedagogia própria para organizações com potencial de estabelecer uma orientação racional-comunicativa, tendo em vista a força que possui o contexto cultural atual de minar o potencial emancipatório nas organizações. Interessante ressaltar que o autor não nega a presença da racionalidade-instrumental em organiza-

1 É preciso destacar mais uma vez que fora Ramon Garcia o pioneiro na aproximação entre as propostas desses dois autores no meio acadêmico da Administração, como foi mencionado na introdução do presente trabalho. 
ções substantivas; apenas indica a aparente contradição do convívio das duas lógicas racionais opostas, a qual pode ser eliminada quando se estabelece a subserviência de uma em relação à outra:

\begin{abstract}
Assumida essa racionalidade [substantiva], combinada com a necessidade de internalizar conhecimentos baseados em uma outra racionalidade, estritamente instrumental, estabelece-se uma contradição que deverá ser então mediada por um processo de ensinoaprendizagem que neste trabalho será chamado de emancipatório. (...) Sendo, portanto, o processo pedagógico um processo emancipatório e substantivo - voltado a valores - a instrumentalidade presente no conhecimento administrativo é colocada a serviço das pessoas, e não o contrário (COSTA, 2004, p. 5).
\end{abstract}

Outro aspecto de grande evidência nesse tipo de estudos organizacionais é a natureza do processo comunicativo. Muitos autores da Administração têm se valido da TAC para chamar a atenção de como é precário o entendimento da comunicação nos estudos funcionalistas. Como lembram Reis (2002) e Souza (2002), apesar da importância dada ao processo de comunicação na efetivação de mudanças significativas no âmbito organizacional, esse é comumente observado pela literatura exclusivamente em sua forma instrumental, sendo desconsiderada a dimensão simbólica que é constitutiva das mudanças paradigmáticas, ou seja, aquela dimensão na qual se operam os processos subjetivos relacionados às transformações de ordem cultural.

Outro aspecto importante da comunicação organizacional que é negligenciado pela literatura predominante é a produção de sentidos que dão o tom das práticas organizacionais. Sobre esse aspecto, Sachuk e Machado (2004, p. 5) lembram que "o formalismo contribui para que os resultados da linguagem organizacional sejam formas padronizadas de pensar, em grande parte lineares e unidimensionais", e, por isso mesmo, contribuem para a perda de significado do trabalho. As autoras também salientam o efeito da diferenciação hierárquica nesse processo de significação pela comunicação:

...no espaço organizacional a hierarquia contribui para que os comportamentos enfatizem os conteúdos de forma diferenciada. É provável que nos mesmos níveis hierárquicos a manifestação livre dos conteúdos seja mais freqüente do que a encontrada entre diferentes níveis, especialmente dos níveis inferiores para os superiores, pois sentimentos, como por exemplo o medo, podem prejudicar a ação comunicativa (SACHUK e MACHADO, 2004, p. 6).

A partir do que foi exposto nesta breve revisão dos estudos organizacionais brasileiros, podemos pontuar alguns aspectos que se evidenciam. No contexto das organizações formais - que tem no modelo burocrático o seu principal referencial de estrutura, poder e coordenação social - a contrapartida à ação estratégica se dá na medida que se constituem novos modelos, centrados em uma gestão coordenada por princípios racionais-comunicativos (como é o caso das organizações de economia solidária e das ONGs), por estruturas que valorizem a reciprocidade e confiança entre os agentes e pela constituição de espaços de discussão propícios a interações comunicativas plenas. Esses aspectos se manifestam especialmente por meio de instâncias de processos decisórios coletivos e de uma estrutura de normas e regras fundamentadas em princípios éticos sólidos (GARCIA, 1986), nos quais o processo de comunicação organizacional precisa assumir um caráter intersubjetivo, ou seja, fundado no interesse pelo entendimento em vez do interesse estratégico.

Após esta breve apreciação sobre como vem sendo tratada a teoria habermasiana no campo de estudos organizacionais, segue apresentação do contexto em que se estabeleceu o modelo organizacional em análise no presente trabalho, a instituição psiquiátrica. 


\section{A INSTITUIÇÃO PSIQUIÁTRICA $\mathbb{M}$ IODERNA}

A análise de como o mecanismo organizacional de burocratização do comportamento reflete o ethos da cultura moderna de valorização da disciplina, do controle e da verdade científica pode ser verificada com o advento do modelo manicomial como forma de tratamento psiquiátrico da era moderna. Tal modelo organizacional representa bem o impacto que teve a técnica e o modelo de ciências naturais no âmbito ético-moral da sociedade, tendo em vista que, na era moderna, a questão da loucura passa a ser considerada primeiramente a partir do utilitarismo econômico.

O manicômio enquanto tipo organizacional pode ser caracterizado por dois elementos estruturais básicos: o isolamento do doente e o uso severo de um mecanismo burocrático de controle para a manutenção da ordem no âmbito interno da organização (GOFFMAN, 1996). A partir de tais condições estruturais, é possível considerar o modelo manicomial como um caso extremo de condicionamento racional-instrumental que, dado o seu caráter radical de controle e subjugação do sujeito, intensifica os problemas de alienação que derivam do processo organizacional de burocratização. Assim, no modelo manicomial, a contradição subjacente ao sistema burocrático de organização vê-se escancarada na forma ambígua em que se estabelece o telos desse tipo: o manicômio foi feito para curar a doença mental, mas também para excluir e controlar o insano; ao exercer o controle burocrático de forma intensa (totalizante), termina por comprometer a sua função terapêutica.

A partir de tal ambigüidade, muitos esforços acadêmicos têm buscado verificar a perversidade com que esse tipo de organização trata o ser humano. Considerando que, sob a perspectiva administrativa, o manicômio - enquanto instituição total - empreende a burocratização do comportamento (GOFFMAN, 1996), tais esforços encaminham-se no mesmo sentido que a crítica ao modelo burocrático tratada pela sociologia das organizações, ou seja, a denúncia de um modelo epistemológico utilitarista degradante da condição humana.

No século XVII, a psiquiatria passa a ser justificada como saber científico no momento em que "a insanidade conquistou suas dimensões de objeto" (FOUCAULT, 1997, p. 105). O tratamento conduzido por essa disciplina tinha o status de saber especializado e, por isso mesmo, não era questionado. Dessa maneira, a ambigüidade da psiquiatria residia no fato desta ser uma forma de poder altamente coercitiva e por vezes arbitrária, contudo, legítima para a sociedade da época que a via como um importante recurso para o controle e manutenção social. A função disciplinadora dos manicômios reflete, assim, o uso estratégico deste tipo organizacional para o controle social.

Assim, a instituição manicomial se configurou não apenas como uma organização em que se estabelecia a técnica do conhecimento psiquiátrico, já que ela representava a própria técnica psiquiátrica aplicada. Isto porque, com a especialização do conhecimento médico, o manicômio eleva-se ao grau de instituição hospitalar. A despeito dos benefícios que tal desdobramento possa transparecer, ele apenas serviu para intensificar as arbitrariedades da prática psiquiátrica, considerando a influência da disciplina militar sobre a lógica operacional da organização hospitalar (FOUCAULT, 1992). É assim que os mecanismos de coordenação da vida humana nos hospitais - tais como a análise do espaço, a gestão do desenvolvimento da ação, a vigilância permanente e o registro contínuo (FOUCAULT, 1992) seguem o mesmo critério da estrutura militar, ou seja, a severa formalização do comportamento, representada pelo sistema burocrático de controle.

No trabalho de Goffman sobre o caráter totalizante desse tipo de organização, podemos observar mais claramente como tal contradição se faz presente na instituição de tratamento psiquiátrico. Para Goffman (1996), a lógica burocrática é levada ao extremo e atua de forma a degradar o processo de representação do eu, constituindo o que esse autor chamou de 'mortificação do eu', ou seja, um processo gradativo de degradação da individualidade, o qual é resultante da ênfase dada à eficiência, ou, em outras palavras, a racionalização instrumental. 
A denúncia do manicômio é feita por dois movimentos, um denominado por 'anti-psiquiatria' e outro, por 'anti-manicomial'. A antipsiquiatria consiste em um movimento no qual se questiona a validade da psiquiatria enquanto metodologia científica de tratamento da doença mental. Para tanto, seus proponentes buscavam questionar, epistemologicamente, a disciplina psiquiátrica enquanto forma de saber centrada em uma lógica causal e analítico-empírica, e, por isso, não competente para tratar da questão loucura, que era eminentemente subjetiva e não circunscrita ao âmbito objetivo da realidade. Cooper, um dos autores desse movimento, empreende sua crítica à psiquiatria considerando os limites ontológicos da perspectiva empírico-analítica de tal disciplina, especialmente no que tange à apreensão de patologias manifestadas intersubjetivamente. Assim fala o autor:

A racionalidade implícita de semelhantes teorias causalistas, à qual denominamos racionalidade analítica, exclui, por definição, qualquer compreensão de relações de interioridade entre pessoas (às vezes chamadas de intersubjetividade) e, no entanto, são tais relações que medeiam a série de atos que chamamos de 'comportamento esquizofrênico', ou seja, a maneira pela qual a pessoa rotulada de esquizofrênico se objetiva no mundo. Se quisermos compreender esta mediação, se quisermos descobrir a inteligibilidade do comportamento esquizofrênico, ou de qualquer outra espécie de comportamento, necessitamos não apenas de certa técnica descritiva especial, porém de um tipo de racionalidade radicalmente distinto da racionalidade analítica da ciência natural (COOPER, 1967, p. 23).

Já a luta anti-manicomial corresponde a um movimento ativista em prol dos direitos humanos transgredidos nos manicômios, e tem por objetivo principal a denúncia do tratamento desumano dado aos pacientes. Isto se deu a partir de um engajamento político de entidades da sociedade civil que denunciavam os horrores dos manicômios e exigiam das autoridades medidas contra tais instituições. Também alguns profissionais da área de saúde mental se engajaram na causa antimanicomial, pois estavam preocupados com a ambigüidade subjacente ao modelo asilar de tratamento, considerada especialmente pela discrepância entre o compromisso médico de curar e a obsessão pela disciplina e controle dos internos.

A resposta aos problemas sociais levantados pela anti-psiquiatria e pelo movimento anti-manicomial gira em torno de um novo modelo institucional de tratamento e organização, almejado pelo movimento de 'reforma psiquiátrica'. Assim, surge na perspectiva desse movimento reformista a desconstrução da instituição, "caracterizada pela predominância da crítica epistemológica ao saber médico constituinte da psiquiatria" (AMARANTE, 1996, p. 20). Sobressai, então, uma preocupação com medidas que estejam vinculadas à mudança de perspectiva quanto ao saber médico e, por conseqüência, quanto ao tratamento da doença mental, bem como quanto à própria concepção de loucura. É assim que Amarante (1996, p. 76) concebe que

os passos iniciais da desinstitucionalização consistem, pois, no descontruir o paradigma problema-solução, no envolver e mobilizar nesse processo os atores sociais envolvidos, inclusive os internos - já não mais sob o critério de 'desalienação' -, o que permite descobrir que esse não é um problema puramente tecnocientífico, mas também normativo, social e ético (AMARANTE, 1996, p. 76).

O questionamento da estrutura formal e burocratizante do modelo organizacional manicomial e a constatação do seu caráter degradante e ideológico representariam, então, o resultado de tal atitude epistemológica pregada pela vertente desconstrucionista da reforma psiquiátrica (AMARANTE, 1996). Assim, a transformação da lógica de interação humana no âmbito dos hospitais perpassaria, necessariamente, por um processo de democratização do poder, visto como uma conseqüência do sentido humanitário envolto na causa reformista, além do próprio reconhecimento do paciente como sujeito e igual.

$\mathrm{Na}$ verdade, a ruptura com o poder subjacente à autoridade médica que se pretende na psiquiatria, objetivada pelo movimento reformista, perpassa o princípio de reconhecimento mútuo. Várias propostas da reforma psiquiátrica tentam 
concretizar a mudança da perspectiva unilateral que subjaze na instituição médico-hospitalar tradicional para uma forma mais igualitária entre o corpo dirigente e os pacientes. Uma dessas é a inserção de um sentido de comunidade terapêutica no âmbito da organização psiquiátrica. Apesar de ter identificado sérios problemas na sua forma conceitual original, Basaglia et al. (1994) percebem na idéia de 'comunidade terapêutica' um forte potencial emancipatório dos problemas gerados pelo caráter ideológico assumido na prática psiquiátrica tradicional.

Os autores consideram que o conceito de comunidade terapêutica pressupõe uma contraposição à relação tradicional médico-paciente, tendo em vista ser tal forma "um conjunto orgânico não hierarquizado de médicos, pacientes e pessoal auxiliar" (BASAGLIA et al., 1994, p. 13). Todavia, esses autores ressaltam que, dado os conflitos e ambigüidades que perpassam pelo processo de democratização, pode ser que surja uma ideologia comunitária que representaria uma nova forma de controle e dominação grupal. Para impedir tal anomalia, faz-se necessário o favorecimento da autocrítica e autocontestação, permeando tanto o processo reflexivo individual quanto o coletivo.

Pelo fato da promessa de humanização do doente mental, implícita na concepção de comunidade terapêutica, abarcar um sentido de relação social diferente da lógica racional-instrumental é que vemos a conformidade de todo este esforço de reforma psiquiátrica com a pretensão de saída democrática da teoria crítica de Habermas. Isto especialmente por causa da concepção desse último autor de que a ação genuinamente democrática subsiste em um sistema interativo dialógico, não manipulativo e aberto à discussão (AMARANTE, 1996). No modelo manicomial, a relação de comunicação entre o paciente e a equipe é significativamente estratégica - tendo em vista especialmente o contínuo uso de formas de distorção da comunicação empreendido pela equipe para manipular e controlar os pacientes (AMARANTE, 1996) -; já na proposta de reforma psiquiátrica, a relação comunicativa entre médico e paciente visa à inteligibilidade e confiança, aspectos essenciais no modelo de ação comunicativa.

Tendo em conta o fato de se atribuir ao advento do modelo manicomial como uma das facetas do processo histórico de racionalização da sociedade ocidental, consideramos o caso do desenvolvimento deste tipo organizacional elucidativo para o entendimento da contradição subjacente à orientação racional-instrumental e ao modelo burocrático.

Por outro lado, dadas as premissas da teoria da ação comunicativa de Habermas, consideramos, ainda, que a associação entre a reforma psiquiátrica e o modelo de ação comunicativa é possível por causa da busca de reciprocidade entre o doente mental e o corpo técnico almejada pela primeira. Além disso, vários indícios podem ser observados em favor da hipótese de que a reforma psiquiátrica se propõe, no sentido de institucionalizar um tipo organizacional substantivo ${ }^{2}$.

\section{$\mathbb{M} \mathbb{E} T O D O L O G I \mathbb{A}$}

O presente estudo constitui uma pesquisa exploratória, considerando que se pretende investigar questões ainda não muito esclarecidas, ou seja, as contribuições analíticas que a TAC oferece à área de organizações. Buscamos a utilização de instrumentos metodológicos de caráter ideográfico, seguindo a lógica qualitativa de pesquisa, mas também para permanecer em conformidade com o pressuposto subjetivista que envolve o programa de pesquisa da teoria social crítica

\footnotetext{
${ }^{2}$ Nesse sentido, destacamos a idéia de desburocratização e democratização na reorganização hospitalar pretendida pela reforma psiquiátrica, bem como a busca pela gestão participativa e pelo estabelecimento de processos de comunicação organizacional intensos (AMARANTE, 1996). Finalmente, também deve ser considerado um indicativo da busca pela organização substantiva em alguns processos de reforma psiquiátrica nos hospitais o forte sentido ético-moral nestes processos, idealizados pelas próprias comunidades hospitalares.
} 
de Habermas. Assim, empregamos como técnicas de coleta de dados a observação participante, a entrevista e a análise documental ${ }^{3}$. O nível de análise é o organizacional, sendo a unidade de análise os membros da organização, mais especificamente, os funcionários, dirigentes, pacientes e familiares. O caso escoIhido é o de uma instituição psiquiátrica filantrópica, conhecida por ter empreendido um processo radical de reforma psiquiátrica.

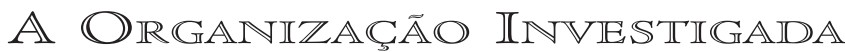

A organização escolhida para o presente estudo foi o Hospital Espírita de Psiquiatria Bom Retiro - HEPBR, situado em Curitiba-Pr. A seguir, tem-se uma breve apresentação da instituição ${ }^{4}$, a partir de agora denominada de Hospital Bom Retiro.

O Hospital Bom Retiro corresponde a uma organização sem fins lucrativos, justamente por configurar-se juridicamente como um departamento da Federação Espírita do Paranás. Sua principal atividade-fim é o atendimento e tratamento especializado em psiquiatria, porém, envolvendo várias outras especialidades de caráter terapêutico (psicologia, terapia ocupacional, enfermagem etc.). A organização atua nos problemas de transtornos mentais, alcoolismo, drogadição e psicogeriatria, sendo o primeiro o que corresponde a maior parte das atividades do Hospital.

O sistema de trabalho é dado especialmente pelo processo de internamento dos pacientes, a partir de duas modalidades: o internamento voluntário, em que o paciente por livre e espontânea vontade opta por internar-se, e o involuntário, cujo internamento ocorre de acordo com determinação judicial ou por ação da família. Entretanto, apesar desta distinção, em ambos os casos, é possível obter a alta imediata do paciente, seja por pedido dele mesmo ou por pedido da família, para a qual se impõe a única condição de se assinar um termo de responsabilidade pela interrupção do tratamento. Ademais, existe todo um cuidado no Hospital em não se caracterizar o internamento como um procedimento cronificante ${ }^{6}$ e asilar, utilizando, assim, uma política de brevidade ${ }^{7}$ e de visitações freqüentes ${ }^{8}$. Também existem no Hospital formas de tratamento sem reclusão, especificamente, o atendimento ambulatorial, o atendimento empreendido pelo Centro de Atendimento Psico-Social e o 'hospital-dia'.

\footnotetext{
${ }^{3}$ A observação participante perdurou por um período de cinco meses. As entrevistas foram semiestruturadas e abertas, e objetivaram o levantamento de informações que serviram para contextualizar os dados constituídos durante o período de observação. Na análise documental foram utilizados três tipos de documentos: o material informativo e instrucional dirigido à comunidade do hospital (apostilas, folders, texto do web site etc), as atas de reuniões e assembléias nas quais o pesquisador não estava presente e o livro de ocorrências da unidade funcional onde realizamos mais diretamente a atividade de observação participante. Este último documento era recorrido todas as vezes que necessitávamos checar a natureza de acontecimentos noturnos e de outros períodos em que estávamos ausentes e que porventura surgiam nas falas e/ou transpareciam nas situações observadas pelo pesquisador.

${ }^{4}$ A descrição que se segue corresponde às características atuais da instituição em questão, a qual representa a fase em que já se consolidou o processo de reforma no modelo manicomial, iniciado a partir do ano de 1984. No item sobre o histórico do Hospital Bom Retiro, mencionamos a fase manicomial da instituição sem descrevê-la em detalhes, pelo fato desses serem os mesmos que foram tratados na descrição do modelo manicomial que consta na revisão teórica do presente artigo. ${ }^{5}$ A Federação Espírita do Paraná - FEP - é uma das entidades federativas do movimento espírita brasileiro. É a instituição que, no Paraná, representa o espiritismo, uma filosofia de cunho religioso com forte conotação caritativa (KARDEC, 1999). A FEP desenvolve diversos trabalhos assistenciais para a comunidade da cidade de Curitiba, sendo o atendimento oferecido pelo Hospital Bom Retiro um deles. ${ }^{6}$ A idéia da cronificação, a qual Foucault (1997) chama a atenção, diz respeito ao processo de 'adoecer através da instituição que cura' e que corresponde a uma das mais significativas contradições do modelo manicomial.

7 Durante a observação, verificamos que os internamentos duravam, em média, 20 a 30 dias, e que esse período raramente excedia 60 dias.

${ }^{8}$ Em todas as unidades funcionais do Hospital Bom Retiro, os dias para visitações regulares contam com três ou quatro na semana, sendo que, dependendo do caso, são possíveis visitas diárias.
} 
No total, a instituição possui 712 vagas, sendo 272 de internamento com pernoite. O quadro de funcionários conta com um total de 210 pessoas, sendo 110 profissionais da equipe técnica e 100 funcionários dos serviços auxiliares (cozinha, lavanderia, limpeza e manutenção, telefonista e recepção, auxiliares administrativos etc.). A estrutura operacional é matricial: existe uma linha diretiva orientada de acordo com a divisão por unidades funcionais transpassada por uma linha operacional dos serviços de atendimento terapêutico/auxiliares. A direção do hospital é constituída por quatro membros: uma diretora geral, um diretor clínico, um assessor geral e um assessor técnico. Para cada unidade funcional, bem como para cada tipo de serviço (terapêutico ou auxiliar), existe um coordenador (em todos os casos é um membro da equipe técnica da unidade que coordena).

O Hospital Bom Retiro tem por filosofia institucional o tratamento interdisciplinar, a qual está baseada na perspectiva terapêutica holística dada pela visão de ser humano enquanto um complexo bio-psico-culturo/sócio-espiritual ${ }^{9}$. Assim, a estrutura de trabalho leva em conta um sistema operativo de equipes multidisciplinares que atuam de forma integrada, alocadas em unidades funcionais de tratamento. Dessa maneira, cada unidade funcional conta com uma equipe interdisciplinar de tratamento, com profissionais de psiquiatria, psicologia, enfermagem, terapia ocupacional e serviço social.

O tratamento ocorre a partir do desenvolvimento de uma psicoterapia de grupo, em que participam os terapeutas, os pacientes e seus familiares. Tal metodologia tem por objetivo a diminuição do uso de medicamentos, e é complementada por atividades ocupacionais de caráter sócio-terápico que, como é declarado no website institucional do hospital ${ }^{10}$, visa a "desenvolver no paciente sua auto-confiança e recursos para se reintegrar à família e à sociedade".

Por ser um hospital espírita ${ }^{11}$, o Bom Retiro conta com um serviço de atenção espiritual - SAE, um setor com atributos de unidade funcional. O SAE tem como atividades essenciais a coordenação e efetuação da fluidoterapia, a consecução de palestras semanais oferecidas aos pacientes e funcionários sobre a moral espírita, e o atendimento aos casos caracterizados como sendo de obsessão espiritual ${ }^{12}$.

Na seqüência, tratamos do histórico do Hospital Bom Retiro, no intuito de melhor elucidar sobre as condições e aspectos contextuais que deram ensejo ao processo de reforma psiquiátrica nessa organização.

\section{IHISTÓRICO DO BOMI RETIRO}

A inauguração do Hospital Bom Retiro ocorreu no ano de 1946, todavia, o projeto de sua realização remonta a década de vinte $(\mathrm{SECH}, 1987)$. A idéia inicial era criar um hospital espírita, exclusivamente para o tratamento de transtornos

\footnotetext{
${ }^{9}$ Essa perspectiva holística do sujeito é nitidamente influenciada pela visão cosmocêntrica da doutrina espírita. De acordo com o espiritismo, a complexidade da natureza humana reside na sua multidimensionalidade que extrapola a concepção material e mesmo ontológica da vida única. Essa idéia deriva de dois princípios essenciais da doutrina espírita: i) a positividade da dimensão espiritual e sua interatividade com o mundo material e ii) a pluralidade das existências, dada pela idéia de reencarnação (KARDEC, 1999).

10 Disponível em: <http://www.hospitalbomretiro.com.br> Acesso em 20 de agosto de 2005.

${ }_{11}$ Membros da diretoria do Hospital Bom Retiro fazem questão de destacar que na denominação da instituição, o atributo 'espírita' aparece anteriormente ao 'psiquiátrico', isto devido à importância que devem ter as atividades de cunho espiritual na instituição.

12 De acordo com Sech (1987, p. 2), o termo obsedado corresponde a uma "terminologia espírita que significa estar a pessoa desequilibrada pela ação obsessiva de uma entidade espiritual desencarnada".
} 
considerados de natureza espiritual ${ }^{13}$. Como não foi possível consolidar tal idéia devido ao preconceito da época ao espiritismo, o Hospital iniciou suas atividades sob o rótulo de sanatório e a partir dos moldes manicomiais vigentes nas instituições daquele tempo.

Da sua inauguração até o ano de 1980, o 'sanatório' Bom Retiro manteve praticamente inalterada sua estrutura institucional manicomial. Em função disto, muitos dos fundadores do hospital (que ocupavam cargos importantes na Federação Espírita do Paraná) frustravam-se com as distorções da proposta inicial de um hospital de caráter espírita, tendo em vista especialmente as barreiras colocadas pela direção clínica da época quanto a atividades espíritas dentro do hospital. No mais, o caráter iatrogênico e cronificante que a instituição abarcava chocava-se com os ideais de fraternidade apregoados pelo espiritismo ${ }^{14}$. Assim, os dirigentes da entidade espírita mantenedora do Hospital começaram a pressionar o diretor clínico da época para que fossem efetuadas mudanças no modelo institucional. De 1980 a 1984, tais mudanças ocorreram no sentido de se tentar recuperar a idéia inicial. Para tanto, em 1981, foi destituída a diretoria do hospital e em 1982 alterou-se o nome de 'sanatório' para 'hospital espírita de psiquiatria'.

Em 1984, com a mudança da diretoria da entidade mantenedora, novamente se modificou o corpo de dirigentes do Hospital Bom Retiro. Foram nomeados quatro profissionais da área de saúde mental com forte participação no movimento espírita paranaense, os quais permanecem na direção do hospital até os dias de hoje15. A partir desse último corpo de diretores, ocorreram mudanças institucionais significativas, já que, desde sua posse, os quatro membros buscavam implementar um novo programa de trabalho e uma nova filosofia de tratamento psiquiátrico.

Para tanto, os novos diretores valeram-se da sua autoridade e poder instituídos para conseguir romper as barreiras do antigo corpo clínico deliberativo. Quando questionado sobre as resistências do antigo corpo clínico, o assessor geral (que é médico psiquiatra de formação) respondeu o seguinte:

\begin{abstract}
Nós tivemos que enfrentar. Toda transformação enfrenta muita resistência, e os psiquiatras que estavam no hospital, levando o hospital durante muitos anos... 'sabiam'... e o 'saber'restringe muito... Então, para essa abertura nós tivemos que enfrentar grandes barreiras, tivemos que muitas vezes nos indispor com muita gente...mas nós tínhamos um plano, tínhamos um grupo, tínhamos um planejamento e isto foi feito gradativamente. E muitos daqueles que resistiam começaram ver como era diferente essa forma de trabalhar. $E$ aos pouquinhos foram ou abrindo mão da sua posição e aderindo ou pedindo afastamento. Não é todo mundo que se adapta a esse sistema... alguns passaram por aqui, resistiram certo tempo, alguns tentaram se acomodar mas não fazia a sua forma de trabalhar e pediram para sair... e gradativamente houve essa decantação de uma equipe que eram aqueles elementos que estavam mais afinados com essa forma de trabalhar.
\end{abstract}

\begin{abstract}
${ }^{13}$ A doutrina espírita pressupõe que, devido a factualidade de um mundo espiritual e sua interação com o mundo material, grande parte dos transtornos mentais se explicaria antes como um fenômeno espiritual denominado 'obsessão'. A obsessão espiritual corresponde a uma influência maligna de um espírito desencarnado sobre uma pessoa encarnada, por meio de uma faculdade denominada mediunidade - que, de maneira muito simplificada, corresponde à capacidade de perceber os espíritos, especialmente pela audição e visão (KARDEC, 1999). De acordo com o espiritismo, grande parte dos diagnósticos de transtornos mentais na, verdade, são fenômenos mediúnicos e obsessivos, fato que justificaria um tratamento específico, diferente daqueles da psiquiatria tradicional.

${ }_{14} \mathrm{O}$ espiritismo é uma doutrina religiosa, e prescreve aos seus seguidores uma ética fundada na moral cristã, especialmente nos princípios da caridade. De acordo com a doutrina espírita, o crescimento espiritual (objetivo maior do ser humano) é obtido especialmente pela prática da caridade (KARDEC, 1999).

15 Os cargos ocupados pelos quatro diretores são: diretor geral, diretor clínico, assessor geral e assessor clínico.
\end{abstract}


Como sugere o depoimento acima, um importante passo para a transformação no Hospital foi o estabelecimento de um novo programa geral de funcionamento. Esse programa tinha como premissa a interdisciplinaridade, e buscou dar condições para que o tratamento fosse mais completo e abrangente. Para tanto, ampliou-se a equipe técnica e se reestruturou os pavilhões em unidades funcionais, nas quais a equipe ficaria alocada a partir de então. Outro fato importante foi a flexibilização da estrutura de poder do médico. De acordo com o diretor clínico, houve uma "igualização em um mesmo plano de todas as especializações estabelecendo uma multidisciplinaridade sem hegemonia" (SECH, 1987, p. 3) ${ }^{16}$. A 'igualização' foi dada especialmente no sentido de romper com a premissa do modelo tradicional do poder do conhecimento médico, que se sobrepunha aos outros conhecimentos e especialidades no processo de tratamento. A única função diretiva que há na equipe da unidade é a figura do coordenador de unidade, que pode ser qualquer um dos técnicos.

Um dos motivos que deu ensejo à reforma institucional no Hospital Bom Retiro dizia respeito às restrições da gestão anterior quanto aos trabalhos de cunho espírita. Por isso, uma das transformações mais significativas foi a oficialização de atividades vinculadas ao espiritismo na rotina de trabalho. Isto ocorreu com a criação do Serviço de Atendimento Espiritual - SAE, um departamento criado para desenvolver e coordenar todas as atividades de assistência espiritual aos pacientes, familiares e mesmo funcionários. De acordo com o assessor técnico, "a importância do SAE para o Bom Retiro se mede pelo fato deste departamento integrar o programa terapêutico". Foi somente com a implementação do SAE que, de fato, pôde-se concretizar a proposta inicial dos idealizadores do hospital.

Nesta breve exposição do histórico do Bom Retiro, vimos quais são os pontos significativos para a verificação da ação comunicativa nessa organização. O esforço reformista dos diretores que assumem o hospital em 1984 deu-se no sentido de equalizar a estrutura hierárquica de poder - especialmente neutralizando o poder hegemônico e arbitrário do psiquiatra. A ruptura ocorre objetivamente pelos processos de formalização de instâncias coletivas de decisão, mas, também, subjetivamente a partir da construção de uma nova representação da atividade terapêutica que considera como fundamental a reciprocidade entre os membros da comunidade hospitalar, o que, por si só, já indica a ruptura de uma lógica tecnoburocrática para a comunicativa (Felts, 1992). Nesse último ponto, é evidente a influência da ética espírita na consecução de tal intento ${ }^{17}$, fomentada no âmbito organizacional pelos diretores em sua prática de gestão e reforçada pelos outros membros ligados ao movimento espírita, que, a partir de 1984, tiveram maior presença no hospital ${ }^{18}$.

\footnotetext{
${ }^{16}$ Este texto foi utilizado na análise documental. Corresponde a um trabalho apresentado pelo referido diretor em congresso acadêmico, utilizado no Bom Retiro como material de estudo para treinamento de estagiários e novos funcionários.

17 A ética espírita é sustentada pelo ideal da igualdade do respeito às diferenças. Além disso, como já o dissemos, essa doutrina é fortemente condicionada pela prática do altruísmo (KARDEC, 1999). ${ }_{18}$ Durante a nossa pesquisa de campo, percebemos que grande parte dos funcionários atuais no Bom Retiro é adepta do espiritismo, e o restante é, no mínimo, simpatizante dos princípios da moral espírita. Verificamos que, em certas ocasiões, persiste alguma divergência referente a questões religiosas na comunidade hospitalar. Isso é comum quando novos funcionários contratados ou certos pacientes internados são adeptos de outras religiões, e estes questionam as práticas fundadas no espiritismo. Nessas situações, o desfecho quase sempre é o afastamento do funcionário (voluntário ou deliberado) ou a transferência do paciente (por vontade própria ou da família).
} 


\section{APRESENTAÇÃO $\mathbb{E}$ ANÁlLISE DE DADOS $\mathbb{D}^{19}$}

Para que pudéssemos verificar a dimensão de uma orientação racional comunicativa ou instrumental na organização investigada, constituímos o quadro de análise do presente trabalho a partir de três categorias que indicam o conjunto de processos organizacionais escolhidos para que se verifique a natureza racional predominante na organização. Essas categorias são o processo decisório, o processo de comunicação e o sistema de normas e regras.

\section{O PROCESSO DECISÓRIO}

O processo decisório do Hospital Bom Retiro tem por princípio fundamental a coletivização da tomada de decisão. Para tanto, existe um amplo sistema participativo para discussão e tomada de decisão, dividido em diferentes instâncias de decisão coletiva ${ }^{20}$. A divisão das instâncias segue apenas um critério de funcionalidade, o que define a própria estrutura divisional do Hospital Bom Retiro.

O princípio que perpassa por todas as instâncias de tomada de decisão é a de que tais reuniões constituem fóruns abertos de discussão e deliberação coletiva. Nesse sentido, o consenso é obtido pelo entendimento claro das questões e dos posicionamentos apresentados pelos participantes, já que as condições de tais esferas deliberativas estimulam a participação ativa de todos, muitas proposições são levantadas, além de proporcionar debates intensos. Isto é sentido especialmente nas reuniões de coordenadores e de diretoria, bem como nas reuniões de serviço dos profissionais de nível superior, por exemplo, os médicos, os psicólogos e os terapeutas ocupacionais. O depoimento do coordenador do SAE sobre a reunião de coordenadores demonstra o teor da lógica cooperativa:

A reunião de coordenadores é muito aberta. Cada um pode agendar o que achar por bem. Eu vejo que ali há muitas vezes cobranças de uma unidade para a outra... Mas, saiu dali, tá todo muito bem, todo mundo em ordem. A única intenção é acertar mesmo. Não fica aquelas 'correntes', sabe, que a gente vê em organizações convencionais, da indústria, do comércio, e tudo o mais, que sempre fica as 'panelinhas', alguns conflitos... E ali não, ali tudo é colocado pra fora na hora, é falado de tudo, é cobrado de tudo, mas a única intenção é acertar. (...) E a própria direção expõe suas dificuldades com clareza. Então, dificilmente vem uma coisa de cima para baixo.

O clima informal é predominante nas diversas reuniões no Hospital Bom Retiro. Neste sentido, duas das características mais marcantes de tais processos deliberativos são a cordialidade e a liberdade para expressar livremente uma opinião e um sentimento. Independente do cargo que se ocupa, os funcionários de modo geral sentem-se à vontade para opinar, para criticar e para discordar. Quanto à cordialidade das interações de discussão, a opinião de uma das coordenadoras de unidade funcional é a seguinte:

\footnotetext{
19 Vale ressaltar que a descrição aqui apresentada corresponde ao período atual do Hospital, onde já havia se passado 20 anos da posse da diretoria que empreendeu o processo de reforma psiquiátrica. Assim, o objetivo desta apresentação é verificar em que medida foi possível a consecução de novas práticas sintonizadas com o modelo de ação comunicativa. Partindo do pressuposto de que o modelo que vigorava até 1984 era o manicomial e que suas bases tecno-burocráticas já são conhecidas (considerando a discussão na seção do presente artigo que trata do modelo manicomial) ao constatarmos os aspectos substantivos nos três processos analisados, podemos verificar em que medida é possível a transição de uma orientação racional-instrumental para a racionalidade comunicativa.

20 Existem cinco diferentes instâncias: as reuniões de equipe da unidade (nas quais participam todos os membros da equipe terapêutica), as assembléias da unidade (participam a equipe terapêutica e os pacientes da unidade), as reuniões de coordenadores de unidade, as reuniões de serviços (participam os profissionais de uma mesma especialidade) e as reuniões de diretores. Todas essas instâncias têm regularidade semanal.
} 
Em todas as reuniões que a gente participa, a gente vê que as pessoas se preocupam em não agredir os outros com aquilo que vão dizer. Não quer dizer que a gente não diz o que devia. A gente fala mesmo. Só que a gente diz de um jeito que não ofende. O importante é saber como dizer. O importante é o jeito de dizer.

Grande parte do caráter participativo dos processos decisórios do Hospital Bom Retiro deve-se à postura dos detentores de autoridade formal. De modo geral, os coordenadores e diretores buscam dividir o poder de decisão, seja por meio de uma postura de reconhecimento do outro como um igual, seja buscando sancionar as decisões acordadas nas reuniões de seu grupo. É importante destacar que o poder final de tomada de decisão reside no cargo de comando (ou seja, a estrutura deliberativa dos fóruns deve ser sempre sancionada pelos responsáveis formais de cada unidade ou setor), mas, na prática, as decisões deliberadas nos diversos fóruns são sempre acatadas pelos diretores. Assim, de modo geral, a atitude das chefias quanto à autoridade era a de um auto-reconhecimento como integrante de uma equipe auto-gerida.

Neste sentido, a principal função da coordenação é a de representar a unidade perante a direção geral (especialmente nas reuniões de coordenadores), além de servir de elo de comunicação entre a unidade e as outras instâncias. A esse respeito, vejamos o depoimento de uma coordenadora de unidade funcional sobre o caráter da função de coordenação:

Eu não sou chefe... Eu divido com todas as pessoas dentro da minha equipe. Eu estou nessa função como representante. Eu levo notícias e trago notícias... Mas não que essa função dependa de mim. É repartido em grupo. Então eu não me sinto nem mais nem menos do que nenhum deles, eu me sinto junto com todos. Desde a servente até o paciente.

Entretanto, apesar de ser comum o entendimento entre as chefias de que se deve dividir com seus grupos a autoridade, o reconhecimento dessa postura de reciprocidade nem sempre é correspondido pelos subordinados. Algumas vezes, o cargo de comando intimida aqueles que estão em níveis hierárquicos inferiores. Isto ocorre especialmente em relação à diretora geral. Apesar da receptividade dela às opiniões e mesmo reclamações de qualquer funcionário do hospital, esse nem sempre se sente à vontade para procurá-la. Tal 'receio da autoridade' transparece claramente no seguinte depoimento do auxiliar administrativo da diretora geral:

Tem muito colega nosso que nos procuram pra falar alguma coisa que gostariam de falar com a doutora [diretora geral], mas eles têm medo... Acham que é algo bobo demais pra levar pra direção, ou ficam constrangidos de falar com ela. Eles falam com a gente porque se sentem mais próximos, acham que eu sou um igual.

De acordo com esse depoimento, a diferença entre o nível hierárquico da diretora geral e o dos funcionários é o fator inibidor de uma relação comunicativa em plenas condições de reciprocidade e confiança. Tal fato corrobora a idéia de que a diferenciação hierárquica corresponde a um constrangimento pré-lingüístico e que induz à inibição no processo comunicativo (FELTS, 1992). É interessante ressaltar que a situação inibidora ocorre a despeito da postura pessoal da diretora geral em buscar uma maior aproximação com os funcionários de nível mais baixo.

Além da postura das lideranças mencionada acima, a equidade entre os membros do Hospital é favorecida pela idéia de que todos os profissionais têm a mesma importância para o tratamento dos pacientes. Tal perspectiva foi possível graças à idéia de agente terapêutico, um conceito criado pelos membros do Bom Retiro para orientar a prática terapêutica e a vida organizacional. Basicamente, essa idéia consiste no entendimento de que toda pessoa que tem algum contato com o paciente é um agente terapêutico, justamente pelo fato de sua relação incidir de alguma forma no desenvolvimento do tratamento, seja por um estímulo à reação do doente ou por uma contribuição aos outros colegas da equipe terapêutica. 
Assim, sob a égide da idéia de agente terapêutico, a importância da opinião de uma faxineira se equivale a de um médico, tendo em conta que ambos têm contato com o paciente e, por isso, são responsáveis pelo seu tratamento. O assessor geral do Hospital nos deu a seguinte explicação sobre os motivos que deram ensejo ao surgimento desse conceito, sobre a sua importância e sobre algumas conseqüências:

\begin{abstract}
A grande revolução que se conseguiu fazer aqui no hospital foi a quebra da onipotência da psiquiatria. A visão que se tinha antes do papel do médico era a de que ele que sabia, ele que dava alta, ele que medicava... Mas ele praticamente acompanhava muito pouco o tratamento do paciente, que ficava mais na mão da enfermagem. Aí, a nossa visão era a de que todo o participante que entrava em contato com o paciente é um agente terapêutico, no sentido, então, de trabalho em equipe. Desde a servente que limpa o chão até o psiquiatra que é o responsável legal pelo tratamento terapêutico, são agentes terapêuticos. E nós aqui conseguimos fazer até que, com este tipo cooperativo, os outros pacientes se transformassem em agentes terapêuticos também, favorecendo então que esta comunidade se ajudasse mutuamente e perdendo aquela característica de um principal dentro da equipe.
\end{abstract}

O depoimento anterior é muito elucidativo para o entendimento de como o conceito de agente terapêutico contribui para a disseminação de uma ideologia de igualdade por entre os membros da comunidade hospitalar (incluindo aqui, além dos funcionários do hospital, os pacientes e seus familiares). Assim, a princípio, todos têm os mesmos direitos e a mesma carga de responsabilidade, ou seja, a todos é dado o mesmo espaço, já que tal ideal surge no sentido de anular a diferenciação por status.

Outra questão interessante do sistema participativo de tomada de decisão do Hospital Bom Retiro é a abertura para a participação dos pacientes, desenvolvida a partir das assembléias. É claro que, devido ao fato de muito dos internos abarcarem patologias que dificultam um estado mínimo de consciência, são os pacientes com um melhor estado de lucidez - situação geralmente referente aos níveis mais avançados do tratamento - que participam mais ativamente dos processos decisórios. Assim, nas assembléias, os internos também expressam opiniões, fazem críticas e dão sugestões sobre os procedimentos terapêuticos, sobre a rotina na unidade, sobre acontecimentos, sobre a equipe técnica, sobre os outros internos etc.

Vários são os aspectos que atestam ser o processo decisório no Hospital Bom Retiro orientado para ação comunicativa. O fato de serem articuladas diversas instâncias de discussão é um deles, já que, conforme salientado por Paula e Motta (2003), no seu estudo sobre as práticas de gestão pública orientadas substantivamente, a proliferação de instâncias e fóruns de discussão e deliberação coletiva promovem o engajamento dos sujeitos. Além disso, a institucionalização dessas múltiplas instâncias deliberativas permite uma dinamicidade das relações que enriquece o aprendizado e a mudança (REIS, 2002; COSTA, 2004).

Outro aspecto que merece destaque diz respeito às condições subjetivas para a participação plena. O clima de informalidade nitidamente surge em contraposição ao formalismo da estrutura burocrática, lembrado por alguns autores como um constrangimento pré-linguístico inibidor da prática comunicativa plena (FELTS, 1992; SACHUK e MACHADO, 2004). Vale ressaltar que, no Bom Retiro, existem limites na busca pela reciprocidade, e esses são verificados especialmente quando o constrangimento do cargo persiste na relação entre os membros. Finalmente, o conceito de agente terapêutico aliado ao significado da função de coordenador indica a necessidade de se estabelecer uma resignificação das relações em torno de uma orientação idealizada do bem comum sobreposta ao interesse particularista e da mera dimensão funcional das relações, conforme salientado por alguns estudos de organizações substantivas (ANDION, 2001). 
A comunicação transparece como algo de grande importância para o funcionamento do Hospital Bom Retiro, tendo em vista especialmente o seu sistema participativo de tomada de decisão, e, por isso, dedica-se grande parte das atividades de gestão em processos de comunicação. Mesmo nas atividades terapêuticas, a essência dos processos de interação é o seu aspecto dialógico ${ }^{21}$.

A natureza dos processos de comunicação em todos os fóruns de discussão estabelecidos no Hospital Bom Retiro é essencialmente dialógica, ou seja, aquela que, de acordo com o modelo habermasiano, busca a inteligibilidade para se atingir o entendimento mútuo dos comunicantes sobre todos os aspectos considerados no ato de fala, sejam eles objetivos, subjetivos, éticos ou morais (SACHUK e MACHADO, 2004). Isto pode ser demonstrado ao se observar que, nas diversas discussões, existe uma grande preocupação dos membros em fazerem-se compreendidos, em esclarecer as dúvidas quanto aos pontos de vista ou mesmo argumentos considerados na fala. Neste sentido, quando surgiam desacordos em relação às posturas ou opiniões, os participantes tendiam a intensificar os debates por meio da argumentação. Quando se verificavam dificuldades na aceitação de propostas, geralmente os propositores esforçavam-se para enriquecer a sua fundamentação, valendo-se de argumentos supostamente baseados em um sistema de valores e princípios compartilhados por todos os participantes.

Talvez o ponto mais evidente da intenção de se estabelecer a comunicação dialógica no Hospital Bom Retiro seja a preocupação em configurar a reciprocidade nas interações comunicativas entre a equipe e os pacientes. Assim, na prática terapêutica do Bom Retiro busca-se primeiramente dar voz ativa aos internos, para que esses deixassem de ser os sujeitos passivos e possam participar mais da vida organizacional.

Outra maneira obtida pela equipe terapêutica para melhorar a comunicação com os internos foi o enriquecimento da relação discursiva a partir da preocupação com a compreensão dos motivos da adoção de certas medidas, das decisões, das regras, das contenções etc. Mesmo com relação aos pacientes de estado patológico mais grave, percebemos que existe uma grande preocupação com a compreensão destes acerca das razões das ações, como demonstra o seguinte depoimento de uma auxiliar de enfermagem sobre uma situação de contenção dada a partir de um ato agressivo de uma paciente:

Quando a paciente esta muito confusa e se está fazendo o grupo de ajuda e ela fica falando, a gente explica o porquê da advertência ou da contenção mesmo assim, mesmo ela estando confusa... Às vezes, alguém pode dizer que isso não adianta nada porque ela não está entendendo. Mas, mesmo assim é bom falar, nem que ela entenda só um pouquinho, isso é muito importante.

Apenas dois tipos de interações nem sempre preservam os princípios de reciprocidade e entendimento visados a sustentar o modelo comunicativo do hospital: as relações entre os técnicos de nível superior - médicos, psicólogos, terapeutas ocupacionais, etc. - e os técnicos de nível médio - as auxiliares de enfermagem -, e as relações entre certo tipo de pacientes e familiares com os profissionais de modo geral. A primeira situação manifesta-se por uma sutil diferenciação entre esses dois grupos; a segunda, pelo comportamento dissimulado de alguns pacientes e familiares, o qual é considerado pelos psicólogos do hospital como "manipulador" (justamente por corresponder à tentativa de manipulação da equipe técnica). Nesse último caso, quando tal ação é bem sucedida, nitidamente se estabelece a distorção comunicativa. Todavia, apesar de ser comum a

${ }^{21}$ Esse último ponto justifica-se pelo fato das principais medidas terapêuticas do Hospital envolverem processos comunicativos (as sessões de psicoterapia das unidades, bem como as de terapia familiar são espaços de discussão). 
'atitude manipuladora', os membros da equipe terapêutica procuram se preservar dela, buscando reconhecê-la.

Seguindo a orientação do modelo de Habermas (1987) sobre interação comunicativa, podemos dizer que, apesar dos casos isolados de manipulação do ato de fala mencionado acima, a estrutura de comunicação que comumente se estabelece no Hospital Bom Retiro atende relativamente bem aos quatro requisitos de validez de um ato comunicativo não distorcido. Na maioria das relações de comunicação observadas, verificamos que: i) existe um largo uso de argumentos fundamentados em um sistema de valores compartilhado pela comunidade hospitalar (requisito de retidão); ii) não transpareceram situações em que se evidenciou o uso de argumentos inverídicos (requisito de verdade proposicional); iii) as manifestações emotivas e sentimentais permeavam todas as situações de interação e eram amplamente utilizadas como argumentos válidos para o direcionamento das atitudes e comportamentos (requisito de sinceridade); iv) sempre que a compreensão das opiniões proferidas não era alcançada, a exposição se dava no sentido de tornar as idéias mais claras (requisito de inteligibilidade).

Além da busca pela satisfação dos requisitos de validez da fala nos processos comunicativos do Bom Retiro verificou-se que esses contribuem significativamente para o estabelecimento do significado das atividades terapêuticas, seja para os pacientes, seja para o resto da comunidade hospitalar. Isto corrobora a tese que vem sendo salientada na literatura de que a comunicação organizacional é fundamental para a estruturação de mudanças institucionais significativas, já que, quando orientadas sob o ponto de vista racional-comunicativa, essas promovem o compartilhamento de novas redes de significado (SOUZA, 2002; SACHUK e MACHADO, 2004), bem como o estabelecimento de processos decisórios realmente democráticos (SOUZA, 2002; TENÓRIO, DUTRA e MAGALHÃES, 2004).

\section{SISTEMA DE NORMAS $\mathbb{E} \mathbb{R} \mathbb{E} G \mathbb{R A S}$}

Além das normas funcionais determinadas por imperativos técnicos e imposições de legislação, foi desenvolvido no Hospital Bom Retiro um sistema de normatização próprio, denominado combinado. Tal sistema é o modelo básico de orientação e estabelecimento de normas internas do Hospital. Todas as coisas que dizem respeito à coordenação do funcionamento interno - horários, escalas de plantões, permissões e proibições - são regidas por algum 'combinado'. Como o próprio nome sugere, a essência é o acordo. Cada combinado é uma regra estabelecida pelo grupo. A princípio, não tem caráter definitivo, pois pode ser questionado e revisto. Conforme nos disse uma coordenadora de unidade, em um depoimento sobre a natureza do combinado: "O combinado tem que ser útil, a partir do momento que ele deixa de ser útil, perde o sentido. Existem combinados que devem ser revistos a partir de um caso específico. Existem regras sim, mas existem sempre exceções".

A despeito da flexibilidade pressuposta no conceito de combinado, de modo geral, a norma assume um severo rigor na sua aplicação, o que corresponde a uma significativa contradição em relação ao próprio sentido não coercitivo pretendido com esse sistema normativo. Os membros da equipe terapêutica do hospital tentam justificar esse rigor pelo fato de terem na instituição muitas atividades que sempre envolvem riscos graves (risco de suicídio, risco de agressão, risco de contaminação, risco de fuga, entre outros).

Assim, contrariamente a um discurso disseminado por alguns dos membros do hospital de que "não se deve ser rígido na aplicação dos combinados, pois, senão, esses perderiam sua essência", paradoxalmente, também, são muito comuns as idéias que pressupõem uma maior rigidez na aplicação, tais como a de que 'não se pode furar o combinado', ou que 'o combinado tem valor de lei'.

A transgressão das normas pode ser entendida pela comunidade do Bom Retiro como um indicativo de que essas devem ser questionadas. Pode-se cogitar 
que a norma não esteja mais adequada (ou, pelo menos, não da forma como essa se apresenta), e, por isso, a sua transgressão significa um sintoma de problema com ela. Nesse caso, primeiro procura-se esclarecer o transgressor quanto aos problemas de sua atitude; depois, cogita-se a possibilidade da norma estar inadequada, e então, a questão é levada para as instâncias de discussão e deliberação. O depoimento de uma coordenadora nos revela esta perspectiva: "Quando o combinado é transgredido é preciso chamar a pessoa para explicar o problema de transgredir, para explicar o porquê da regra. Também deve ser revisto o próprio combinado, pois o problema pode estar na regra".

A lógica dos 'combinados' pressupõe que o sistema de normas e regras do Hospital Bom Retiro é constituído a partir do acordo. Porém, o seu rigor na aplicação e a dificuldade no questionamento das regras mais antigas indicam haver ainda uma forte dependência por um sistema rígido de controle e disciplina.

Por outro lado, busca-se a valorização das instâncias reflexivas da norma a fim de minimizar os efeitos do controle intenso. Assim, sempre se procura a compreensão da norma, seja para aceitá-la melhor ou mesmo para poder questionála. O seguinte depoimento de uma coordenadora de unidade é elucidativo: "existem os combinados, e é importante saber o porquê eles existem. Se você não sabe o porquê das regras, você se sente num quartel". Outro relato, de uma auxiliar de enfermagem, também demonstra esta preocupação com o 'porque' da norma: "O combinado vale porque, quando a pessoa chega, a gente procura explicar certinho o porquê daquele combinado".

Finalizando a questão das normas e regras, podemos dizer que o sistema normativo do Hospital Bom Retiro é fundamentado pelo princípio da democracia pressuposto no modelo racional-comunicativo. Isto corrobora a idéia de que, em organizações substantivas, a dimensão normativa formalizada não deixa de estar presente. Na verdade, tendo em conta a necessidade por uma estrita regulação de atividades e procedimentos (inevitável em organizações hospitalares que tratam de questões de vida e morte, saúde e doença), não se pode omitir a articulação de uma estrutura desenvolvida de normas e regras.

Observado pelo sentido estrito da contraposição dos princípios burocráticos àqueles das organizações substantivas (SERVA, 1996), no desenvolvimento do sistema normativo do Hospital Bom Retiro, há indícios de contraposição à lógica comunicativa (o que foi verificado no fato de haver radicalização do cumprimento da norma, traço significativo da orientação racional-instrumental). Todavia, dada à subordinação da estrutura normativa aos mecanismos discursivos da estrutura organizacional, podemos atestar que, apesar de persistirem certos pontos de conflito e ambigüidade no processo de normatização e regulação, esses não representam ameaça à lógica comunicativa, na medida que se busca conciliá-los a um sistema reflexivo e crítico da norma, conforme salientou Costa (2004) em seus estudos sobre organizações de Economia Solidária. Por isso, a tensão entre orientação racional-comunicativa do sistema de decisão coletiva e os processos normativos rígidos de um hospital (nitidamente uma herança manicomial) é minimizada pela busca da adequada compreensão do sentido das normas, bem como o entendimento quanto ao seu uso.

\section{CONSIDERAÇÕES IFINAIS}

Foi possível verificar, pelo caso estudado, os efeitos da adoção de uma lógica comunicativa na coordenação de uma instituição psiquiátrica. As principais contradições do modelo manicomial - a cronificação, a alienação e a excessiva coerção - puderam ser minimizadas com a adoção de um novo modelo institucional fortemente relacionado a uma lógica racional-comunicativa. Dado os fundamentos da ação comunicativa, pudemos constatar que o princípio da reciprocidade pode ser privilegiado em uma instituição psiquiátrica, seja na relação entre os membros da equipe técnica de níveis hierárquicos distintos, como na relação desses com os 
pacientes. Tal constatação corrobora a idéia de que a reciprocidade entre os membros é algo constitutivo de uma prática organizacional substantiva, centrada na TAC (FELTS, 1992; SACHUK e MACHADO, 2004).

A reforma psiquiátrica no Hospital Bom Retiro inicia-se no ano de 1984, ano em que os atuais diretores assumem o hospital e começam sua jornada de reestruturação do projeto institucional. Como tentamos demonstrar na apresentação e discussão do caso, a transformação de uma estrutura manicomial para um modelo fundamentado em diversas instâncias de discussão e tomada de decisão coletiva deu-se seguindo uma mudança de perspectiva adotada pelos membros do hospital. É importante considerar aqui o fato dessa mudança ter sido grandemente influenciada pelos princípios ético-morais da doutrina espírita.

Uma importante conclusão do presente estudo é que a transição da lógica racional-instrumental para a racional-comunicativa foi possível graças ao estabelecimento de um profundo processo de re-significação da condição humana e da prática terapêutica, o qual desencadeou a contínua adoção de medidas gerenciais características das organizações substantivas. Esse processo sugere que é necessária a mudança constitutiva das representações simbólicas, para que seja bem sucedida a transformação institucional de organizações burocratizadas para modelos baseados em outras racionalidades.

Como foi verificado em nossa revisão teórica, no modelo manicomial tradicional, o sujeito-paciente é renegado a uma condição reificada em nome de uma terapêutica fragmentada e opressora. Essa representação deu ensejo à construção histórica de um modelo organizacional excessivamente burocratizado. $\mathrm{Na}$ medida que os movimentos sociais questionaram os princípios epistemológicos da instituição manicomial, surge um lento, porém contínuo, processo político de reforma institucional, galgado em fortes valores humanitários e preocupado em recuperar a condição de humanidade que havia sido perdida nessas organizações.

No caso do Hospital Bom Retiro, o contexto permitiu que se operasse a resignificação da doença, do sujeito (seja ele o sujeito-paciente ou os outros membros da comunidade hospitalar) e, conseqüentemente, da organização do trabaIho (tanto o terapêutico quanto o administrativo). A doença passa a ser observada em toda sua complexidade sócio-cultural, e o sujeito, na sua condição de agente capaz e detentor de vontade e direitos, estabelecidos dentro de princípios de igualdade e solidariedade.

Dado essas novas concepções da doença e do sujeito, estabeleceram-se as condições favoráveis para que também se operasse a re-significação da organização social do trabalho. Assim, ao longo de vinte anos e ainda hoje (já que esse processo é inacabado), o Hospital Bom Retiro afasta-se gradativamente de práticas de gestão exclusividade guiadas pela eficiência técnico-burocrática em proveito de um modelo de gestão efetivamente participativo, centrado especialmente nas múltiplas instâncias discursivas e em processos comunicativos orientados para o entendimento das várias significações que podem se estabelecer no cotidiano organizacional. Nesse último aspecto, o presente estudo corrobora os resultados obtidos em outras pesquisas teórico-empíricas sobre organizações substantivas, tais como Serva (1996), Andion (2001), Paula e Motta (2003) e Costa (2004).

$\mathbb{R} \mathbb{E} \mathbb{E} \mathbb{R} \hat{E} \mathbb{N} C I \mathbb{A}$

AMARANTE, P. O homem e a serpente. Rio de Janeiro: Fio Cruz, 1996.

ANDION, C. As Particularidades da gestão em organizações da economia solidária. In: ENCONTRO NACIONAL DOS PROGRAMAS DE PÓS-GRADUAÇÃO EM ADMINISTRAÇÃO, 25., 2001, Campinas. Anais...Campinas: ANPAD, 2001 CD ROM.

ASSOUN, P. L. A escola de Frankfurt. São Paulo: Ática, 1991.

BASAGLIA, F. et al. Considerações sobre uma experiência comunitária. In: AMARANTE, P. (org.) Psiquiatria social e reforma psiquiátrica. Rio de Janeiro: Fiocruz, 1994, p. 11-40. 
COOPER, D. Psiquiatria e antipsiquiatria. São Paulo: Perspectiva, 1967.

COSTA, P. A. O ensino de administração para empreendimentos populares: os cuidados metodológicos em busca de uma pedagogia emancipadora. In: ENCONTRO DE ESTUDOS ORGANIZACIONAIS, 3., 2004, Atibaia-SP. Anais...Atibaia: ANPAD, 2004 CD ROM.

FELTS, A. Organizational communication. Administration \& Society, vol. 23, n. 4, p. 495-517, 1992.

FOUCAULT, M. O nascimento do hospital. In: Microfísica do poder. 10. ed. Rio de Janeiro: Graal, 1992, p. 99-111.

FOUCAULT, M. História da loucura. 5. ed. São Paulo: Perspectiva, 1997.

GARCIA, R. M. As redes institucionais de apoio e a produção local de alimentos. Revista de Administração Pública, vol. 20, n. 3, p. 70-80, 1986.

GOFFMAN, E. Manicômios, prisões e conventos. 5. ed. São Paulo: Perspectiva, 1996.

GUTIERREZ, G. L.; FREITAS, M. E.; CATANI, A. M. Em busca da organização democrática: a trajetória de Ramon Moreira Garcia. Revista de Administração de Empresas, vol. 44, n. 2, p. 109-113, 2004.

HABERMAS, J. Teoría de la acción comunicativa. Madrid: Taurus, 1987. 2 vol.

KARDEC, A. O livro dos espíritos. 60. ed. São Paulo: LAKE, 1999.

PAULA, A. P. P.; MOTTA, F. C. P. Administração pública popular: participação cidadã e melhorias sustentáveis na qualidade de vida no Brasil. In: ENCONTRO NACIONAL DOS PROGRAMAS DE PÓS-GRADUAÇÃO EM ADMINISTRAÇÃO, 27., 2003, Atibiaia-SP. Anais...Atibaia: ANPAD, 2003 CD ROM.

RAMOS, A. G. A nova ciência das organizações. 2. ed. Rio de Janeiro: FGV, 1989.

REIS, M. C. S. Comunicação e mudança organizacional: da redução conceitual às lições empíricas. In: ENCONTRO NACIONAL DOS PROGRAMAS DE PÓS-GRADUAÇÃO EM ADMINISTRAÇÃO, 26., 2002, Salvador. Anais...Salvador: ANPAD, 2002 CD ROM.

SECH, A. Bom Retiro: a evolução de um hospital psiquiátrico do clássico para o holístico. In: CONGRESSO HOLÍSTICO INTERNACIONAL, 1., 1987, Brasília. Anais...Brasília: Sociedade Holística, 1987.

SACHUK, M. I.; MACHADO, H. V. Reflexões sobre o processo de comunicação nas organizações. In: ENCONTRO DE ESTUDOS ORGANIZACIONAIS, 3., 2004, AtibaiaSP. Anais... Atibaia: ANPAD, 2004 CD ROM.

SERVA, M. Racionalidade e organizações: o fenômeno das organizações substantivas. São Paulo, 1996. 633 f. Tese (Doutorado em Administração) - Escola de Administração de Empresas de São Paulo, Fundação Getúlio Vargas. 2 v.

SOUZA, Y. S. Finalidade ou linguagem: abordagens para o sentido da ação nos estudos organizacionais. In: ENCONTRO NACIONAL DOS PROGRAMAS DE PÓSGRADUAÇÃO EM ADMINISTRAÇÃO, 26., 2002, Salvador. Anais...Salvador: ANPAD, 2002 CD ROM.

STORINO, G. R. Participação cidadã na gestão pública - dá licença seu doutor? Com a palavra: o povo da favela carioca. In: ENCONTRO NACIONAL DOS PROGRAMAS DE PÓS-GRADUAÇÃO EM ADMINISTRAÇÃO, 25., 2000, Florianópolis. Anais...: ANPAD, Florianópolis: 2000 CD ROM.

TENÓRIO, F. Flexibilização organizacional: mito ou realidade? Rio de Janeiro: FGV, 2000. 
TENÓRIO, F. G.; DUTRA, J. L. A.; MAGALHÃES, C. M. R. Gestão social e desenvolvimento local: uma perspectiva a partir da cidadania deliberativa. In: ENCONTRO NACIONAL DOS PROGRAMAS DE PÓS-GRADUAÇÃO EM ADMINISTRAÇÃO, 28., 2004, Curitiba. Anais...Curitiba: ANPAD, 2004 CD ROM.

TRAGTENBERG, M. Burocracia e ideologia. São Paulo: Ática, 1974.

WEBER, M. Ensaios de sociologia. Rio de Janeiro: Zahar, 1974. 